\title{
KIF20A Gene
}

National Cancer Institute

\section{Source}

National Cancer Institute. KIF20A Gene. NCI Thesaurus. Code C126522.

This gene is involved in both protein trafficking and cytokinesis. 